\title{
Champions during Crises Scenarios: High Growth and Persistent High Growth Firms
}

\author{
Mariasole Bannò ${ }^{1, *} \&$ Celeste Amorim Varum² \\ ${ }^{1}$ University of Brescia, Via branze, 38 - 25125 Brescia, Italy \\ ${ }^{2}$ University of Aveiro, 3810-193 Aveiro Portugal \\ *Corresponding author: University of Brescia, Via branze, 38 - 25125 Brescia, Italy. E-mail: \\ mariasole.banno@unibs.it
}

Received: July 30, 2020 Accepted: June 2, $2021 \quad$ Published: June 24, 2021

doi: 10.5296/rae.v13i2.17461 URL: https://doi.org/10.5296/rae.v13i2.17461

\begin{abstract}
Our paper aims to participate to the growing policy discussion on high-growth firms (HGFs) by analyzing persistence of high growth patterns over crisis. During downturn periods, such as post pandemic one, policy makers seek sources to maintain competitiveness and accelerate growth. Being dynamic players in economic growth and job creation, persistent high-growth firms are notable candidates for assuming that role under such circumstances. Therefore, in this study we explore the determinants and characteristics of HGFs and persistent high-growth firms (PHGF) in a crisis scenario.

We use a sample of 190,247 firms from 2007 to 2014 . We estimate a multinomial probit model with independent idiosyncratic components across the different categories (i.e. HGFs, PHGFs and other firms) using full maximum likelihood. In a second phase we explore which characteristics of HGFs affect the probability of being a PHGFs.

HGFs are characterized by higher productivity and leverage, and PHGFs systematically differ from other HGFs only in what regards degree of international involvement. HGFs probability of maintaining high growth rates is very low.

HGFs are essentially one-hit wonders and it is debatable whether policymakers can enhance economic results by targeting them. Policy makers should be directed towards those firms which have in principal the potential to be winners, but only through policy intervention these aided firms can realize their great potential (i.e. pick and build winner).
\end{abstract}

Keywords: persistent high growth firms, crisis, empirical analysis, public policy 


\section{Introduction}

In todays' economies most firms do not grow, while a little part of them, registering highgrowth, are responsible for a big share of job and income creation (Henrekson and Johansson, 2010; Brown and Mawson, 2013; OECD, 2010). Fast growing firms have been then acknowledged by policy makers as an important source of economic competitiveness able to alleviate unemployment and promote economic growth (Satterthwaite and Hamilton, 2017; European Commission, 2010). This policy interest on high growth firms (HGFs), draws on a number of seminal studies emerging in the late 1970s and early 1980s (see e.g. Birch, 1979; Birley, 1987). Since then, many others defended that the small number of HGFs should be easily identifiable in the community and assisted individually (Ostgaard and Birley, 1996). More recently, an expanding number of researches question the wisdom of picking-winners and conclude that there is weak evidence to justify and support specific public policy measures (Anyadike-Danes et al. 2015).

In this study we do not argue for or against the policy of picking winners, instead we contribute to develop our understanding of high-growth in a crises scenarios.

In the last decades, scolars diverted increasing attention to HGFs and to their determinants (see e.g. Henrekson and Johansson, 2010; Coad and Nightingale, 2014; Audretsch et al., 2014; Coad et al., 2014; Anyadike-Danes et al., 2015;). However, in spite of the numerous contributions, we argue that we still know very little about patterns of high-growth (Anyadike-Danes et al. 2015; Coad et al. 2014). In particular, the demonstrated inability of HGFs to further sustain high growth, suggests that research should focus more on sustained growth (Dillen et al., 2014; Hölzl 2014; Daunfeldt and Halvarsson 2015; Bianchini et al. 2016).

Therefore, in this study, we explore the determinants and characteristics of high-growth and persistent high-growth firms (PHGFs). In particular we want to analyse the characteristics of such firms in a critical scenario. In order to test the growth condition we test the determinants in a crisis scenario, being highly efficient also in this regard (Carré and Guillaume L'œillet; 2018; Giotopoulos and Tsakanikas, 2017). While we know that favorable domestic macroeconomic conditions spur growth, we also observe that some firms do grow faster than others even under crises or recessionary scenarios (Anyadike et al., 2015). During downturn periods, such as Covid-19, decision makers ardently ask for sources to maintain competitiveness and accelerate growth. Being dynamic players in economic growth and job creation, PHGFs are notable candidates for assuming that role also under such circumstances. This aspect is particularly true and important due to the Covid-19 economic consequence. For example at the beginning of February 2020, US unemployment rate was less than $3.5 \%$, one month later ten million Americans filed for unemployment benefits (Baker et al., 2020). The scale of ongoing policies is unique in the modern era.

Due to the lack of near historic analogies to the current crisis, we take as comparison the crisis scenarios of 2008. Of course Spanish Flu pandemic of the beginning of the last century presents a sufficient moment of similarity in terms of death (Barro, Ursua and Weng, 2020; Siddiqui, 2009), but it took place in an economic context that is not comparable to what is happening. In conjunction with the cost of lives and deep health crisis, the world is observing an economic 
downfold that will brutally effect the wellbeing of significant portions of the population in the next years. Unfortunately, researchers have little experience and no guiding academic research addressing supply shocks of this magnitude exists. As such we aim to contribute to knowledge about firm growth and about the eminent policy debate on HGFs by examining persistence of high growth patterns in crises scenarios. This paper provides evidence by addressing two broad questions: are HGFs the superstars most worthy of public support also in crises scenarios? or do they act more like the stunning but evanescent shooting star? Furthermore, which are the distinguishing characteristics of PHGFs? How policy maker can identify target firms to design policy intervention in critical period such as post Covid-19?

Responding to calls by other researchers and, moreover, responding to policy maker's needs, the study undertook a quantitative analysis of a vast population of firms in Portugal trying to suggest best practice policy design. Despite growth patterns may seem to be stochastic it may still be possible to identify a few variables which have a significant impact on growth. Here the dimension and experience of the firm, economic and financial conditions, innovation and internationalization as well the market characteristics in term of degree of concentration and the sector are considered important when trying to understand the growth patterns. We relate HG, PHG and other growth patterns not only to measures of efficiency, profitability and financial conditions, but also to aspects of innovativeness and internationalization, in particular under the crisis scenario.

\section{Theory Background: Insight from Previous Contributions}

Empirical studies on PHGFs address three main questions: if persistence exists; which factors contribute to explain persistence of growth in the following periods? Does persistence exist during crisis? do high and persistent high-growth firms differ between them and with other type of firms? Despite increased research efforts in recent years, our knowledge about PHGFs is still very limited (Dillen et al., 2014; Satterthwaite and Hamilton, 2017). The literature is relatively incipient and highly fragmented and a commonly accepted explanation for persistence does not exist. With the aim to identify potential distinguishing features of PHGFs, existing studies departure from a rich body of knowledge on firm growth and HGFs, as such we review the literature by enlightening the role of specific issues on HGFs and then on PHGFs (Table 1).

In fact, despite growth patterns may seem to be stochastic (Huggins and Williams, 2015; Geroski, 2000), we can find little characteristics that may have a significant effect on this process. In this paper, previous high growth, structural characteristics (e.g. size and age), economic and financial conditions, internationalization and innovation as well the market condition to which the firm operate (e.g. sector and degree of concentration), are judged crucial when aiming to grasp the growth patterns of firms.

Previous high growth. Past studies share an implicit idea that a PHGF must experience high growth for a few time periods. Hölzl (2014) and Daunfeldt and Halvarsson (2015), for example, estimate the probability matrix that describes the transitions across different rankings in the 
growth rates distribution across time. Others (see e.g. Coad 2007; Coad and Hölzl 2009) use quantile regression techniques to demonstrate the degree of autocorrelation in the top quantiles of the growth rates distribution. Bianchini et al. (2016) provide a definition of PHGFs which is at the same time more general than the notion of autocorrelation, and clearly focused over a long run than what implied by a one year or two year transitions.

Regarding the existence of persistence, Coad (2007) and Coad and Hölzl (2009) are probably amongst the first to address the issue of high-growth persistence. On their studies find negative autocorrelation in the annual growth of small fast growing firms. For larger firms they find a positive or not-significant correlation. Acs et al. (2008) find that being a HGF impacts on firm performance on the subsequent years, but firms tend to return to industry average. Hölzl (2014) and Daunfeldt and Halvarsson (2015) explore whether groups of HGFs displays autocorrelation in a standard Gibrat's model. Their results, as well as those from Acs et al. (2008) and Parker et al. (2010) show that persistence of high growth is very rare and suggest that growth is not serially correlated, hence, they support Gibrat's Law.

Most of the existing findings of high-growth persistence determine that high growth is not only sparse but also rarely sustained for more than a few years (Daunfeldt and Halvarrson, 2015). The results tend to indicate that HGFs are one hit wonders, with growth phases that are isolated and unlikely to recur (Dillen et al., 2014; Hölzl, 2014). Satterthwaite and Hamilton (2017) study two cohorts of HGFs covering more than one thousand firms in the 2005 and 2008 cohorts through 2014 in New Zealand. They find that about one out of four of HGFs emerge only to die in the manner of a shooting star. While the majority survived, they maintained much lower growth rates. In a major study conducted for the UK, Anyadike-Danes and Hart (2015) question if one hit wonder is the right label, considering that a significant share of HGFs repeat high growth in consecutive periods. However, the ability of a previous HGF to repeat highgrowth declines over repeated periods.

Hence, overall, the results seem to indicate that HGFs basically are one hit wonders, questioning whether policymakers can establish effective economic policy by targeting HGFs.

Structural characteristics. Age and size are traditional factors recognized for their impact upon firm growth (Li et al., 2008). The literature unanimously supports the idea that HGFs tend to be smaller, younger and more efficient (e.g. Bianchini et al., 2016; Chanut-Guieu and Guieu, 2014). According to existing studies (Acs et al., 2008, Coad and Hölzl, 2009; Dillen et al. 2014) size is likely to increase persistence of high-growth. By contrast, compared to HGFs, Bianchini et al (2016) find PHGFs to be smaller only in some country. Satterthwaite and Hamilton (2017) and Moschella et al (2017) do not find any size effects. Hölzl (2014) and Bianchini et al. (2016), for some cases, find age with a negative effect upon persistence. Dillen et al. (2104) is amongst the few studies revealing some degree of differentiation between HGFs and PHGFs. They find that compared to one shot HGFs, PHGFs are larger, older, with larger assets, but differences are higher when size is measured through employment. They also argue that the profile features of different subsets of HGFs remain relatively constant over time.

Accordingly to them, such an event can be a encouragement for policy makers and government institutions who have introduced programs towards HGFs as the initiatives may benefit from 
the discovering that the subgroups entail of the equivalent category of firms.

Internationalization and innovation. Although relatively less explored, existing results signal that fast growth firms are significantly more internationalized (Brown and Mawson, 2016; Burgel et al., 2003; Hansen and Hamilton, 2011; Mohr and Garnsey, 2011). HGFs are supposed to display high degrees of internationalization, especially export activity (O'Gorman, 2001; Zahra et al., 2000, Nylund et al., 2016). Internationalization through exports enlarges opportunities for growth, especially for firms operating in small regions with limited domestic markets or when the domestic market, for some reason, undergoes a severe decline (Lu and Beamish, 2001, Nylund et al., 2016). To the best of our knowledge, any researches explored the role of internationalization on PHGFs.

Innovativeness have been also found to influence firms' growth (Audrescht et al., 2014). However, PHGFs do not appear to systematically diverge from other high growth firms in terms of innovation (Satterthwaite and Hamilton, 2017; Moschella et al, 2017). Furthermore, on a recent study by Guarascio and Tamagni (2016), the persistence of high-growth was not influenced by persistence in innovation either.

Hence, overall, it seems important for policymakers look at internationalized and innovative firms when creating successful economic policy.

Financial conditions. A set of studies unveil also economic and financial conditions likely to influence firms' growth (Loayza et al., 2017; Haiss et al., 2016). Both good economic performance and financial conditions should create better conditions for growth (Panizza, 2018). However, as clearly revealed by the special issue on Finance and Growth: An Old Debate in a New Challenging Scenario, on Economic Notes(Note 1) these relationships are highly complicated. On the one hand, growing firms are likely to produce extra internal financial resources, and may, therefore, incur less on external debts. On the other hand, these firms may register greater need to resort to external funds given the urge to finance expansionary investments. In addition, external investors may associate HGFs a lower risk premium given their better economic performance, better growth prospects, leading to easier access to credit and therefore to greater exposure to debt. Molinari et al., (2016) suggest that HGFs are characterized by higher growth/cash-flow sensitivities and strongly depend on external debt, but seem to be less bank-backed than non HGFs. In a recent study Bianchini et al. (2016) find mixed results. Their estimates on financial resources provide mixed results, being positive or non-significant for high growth. Conversely, they find robust evidence that HGFs differed from non-high growth ones in terms of leverage: the first ones featured a heavier reliance on debt as compared to own assets. Accordingly, HGFs have access to external finance and they are not completely credit rationed, but they probably have to pay additional for it.

Sector. Existing literature shows that patterns of growth are highly sector and market specific. HGFs are typically in service industries and Bianchini et al. (2016) confirmed that finding also for PHGFs.

From another perspective, Reichstein and Dahl (2004) call our attention to the market structure of an industry, and how it is likely to influence the economic performance and growth patterns. 
Higher competition drives short-run allocative gains, but a more concentrated market structure may induce long-run welfare benefits from a higher innovation activity (OECD, 1996). Even if there is little empirical evidence, firms in high concentrated sectors, by having higher profit margin level, would be more likely to have the funding to join broad innovative projects and then lead into higher growth. Higher concentration should be strongly associated with stronger innovative activity. From a different perspective, the basic idea in the literature on profit persistence is that in most markets firms may earn supranormal profits because barriers of entry and/or the markets are affected by external chocks and/or dominant firms have created intra market mobility barriers. No matter the reason it takes time for competitive forces to work and therefore there may be longer periods where firms earn profits.

Existing studies found in contrast clear sectoral effects as concern PHGFs (Hölzl, 2014). The results from these few studies challenge most theories of firm-industry dynamics sharing the notion that idiosyncratic specificities of firms are the crucial aspects of relative advantages leading to sustained growth over time. Results argue more in support of firm growth as a casual process. As such, some authors conclude that the persistence in HG seems to be correlated to contingent circumstances, whereas not related to structural or sectoral traits (Bianchini et al., 2016).

These results also argue contrary to the long-run efficacy of policies encouraging the formation and support of HGFs.

Table 1. Summary of Studies Addressing High Growth and Persistent High-growth

\begin{tabular}{|c|c|c|c|c|c|}
\hline & Aim & Sample & What is persistence & Method & Conclusion \\
\hline $\begin{array}{l}\text { Coad } \\
(2007)\end{array}$ & $\begin{array}{l}\text { Study autocorrelation } \\
\text { in growth rates, } \\
\text { differentiating by } \\
\text { size. }\end{array}$ & $\begin{array}{l}\text { France } \\
1996- \\
2002\end{array}$ & $\begin{array}{l}\text { Autocorrelation in the top } \\
\text { quantiles of the growth } \\
\text { rates distribution. } \\
\text { Growth measured in sales } \\
\text { and employees. }\end{array}$ & $\begin{array}{l}\text { Linear } \\
\text { and } \\
\text { quantile } \\
\text { regressio } \\
\mathrm{n} \\
\text { analysis }\end{array}$ & $\begin{array}{l}\text { Small firms register negative } \\
\text { correlation of annual growth rates, } \\
\text { larger firms display positive one. } \\
\text { Growth rates in consecutive years are } \\
\text { not independent. High-growth } \\
\text { dependency for large firms }\end{array}$ \\
\hline $\begin{array}{l}\text { Acs et al. } \\
\text { (2008) }\end{array}$ & $\begin{array}{l}\text { Study issues related } \\
\text { with HGFs, including } \\
\text { what happens firms } \\
\text { after their intensive } \\
\text { growth period }\end{array}$ & $\begin{array}{l}\text { USA } \\
1994- \\
2006\end{array}$ & $\begin{array}{l}\text { HGFs are enterprises whose } \\
\text { sales have at least doubled } \\
\text { over a four-year period and } \\
\text { which have an employment } \\
\text { growth quantifier of two or } \\
\text { more over the period. } \\
\text { Follow up growth of HGFs }\end{array}$ & $\begin{array}{l}\text { Demo- } \\
\text { graphic } \\
\text { accounti } \\
\text { ng and } \\
\text { simple } \\
\text { statistica } \\
\text { I analysis }\end{array}$ & $\begin{array}{l}\text { Being a HGF in the previous four years } \\
\text { has a significant impact on firm } \\
\text { performance in the subsequent four } \\
\text { years, and the effect is more evident } \\
\text { as firm-size increases. The most typical } \\
\text { pattern was for gazelles to return to } \\
\text { the industry average. }\end{array}$ \\
\hline $\begin{array}{l}\text { Coad } \\
\text { and Hölzl } \\
\text { (2009) }\end{array}$ & $\begin{array}{l}\text { Study autocorrelation } \\
\text { in growth rates, } \\
\text { differentiating by size }\end{array}$ & $\begin{array}{l}\text { Austria } \\
1974- \\
2004\end{array}$ & $\begin{array}{l}\text { The degree of } \\
\text { autocorrelation in the top } \\
\text { quantiles of the growth } \\
\text { rates distribution. } \\
\text { Growth measured using } \\
\text { employment. }\end{array}$ & $\begin{array}{l}\text { Quantile } \\
\text { regressio } \\
\mathrm{n}\end{array}$ & $\begin{array}{l}\text { Growth in small firms is negative } \\
\text { autocorrelated, growth in larger firms } \\
\text { is positive autocorrelated. Large HGFs } \\
\text { stretch over a longer time horizon. } \\
\text { Larger firms register high-growth } \\
\text { persistence }\end{array}$ \\
\hline $\begin{array}{l}\text { Parker et } \\
\text { al., } \\
(2010)\end{array}$ & $\begin{array}{l}\text { Study why Gibrat's } \\
\text { Law does not } \\
\text { generally hold. } \\
\text { Study which strategy } \\
\text { and external variables } \\
\text { have an influence on }\end{array}$ & $\begin{array}{l}\text { England } \\
1995- \\
2001\end{array}$ & $\begin{array}{l}\text { Recognized extraordinarily } \\
\text { fast-growing firms (gazelles) } \\
\text { over one time period, and } \\
\text { then tracked the same firms } \\
\text { over a second time period. } \\
\text { Gazelles: firms that had }\end{array}$ & $\begin{array}{l}\text { Multi- } \\
\text { nomial } \\
\text { logit } \\
\text { model } \\
\text { and } \\
\text { growth }\end{array}$ & $\begin{array}{l}\text { Growth rate of fast growing firms is } \\
\text { lower in the second time period: } \\
\text { growth is not serially correlated. } \\
\text { While there are links between } \\
\text { strategies and, the same factors do } \\
\text { not powerfully and consistently' }\end{array}$ \\
\hline
\end{tabular}


company

performance

Study why application

of 'best practice' is

unlikely to foster firm

growth.

Study if growth of

consecutive periods is

serial correlated.

Study consistent

factors explain fast

growth in both

periods

Hölzl

Probability of high

(2014)

growth firms to be

high growth in some

future time. gazelles over two

enjoyed rapid sales growth

(30\%) during the previous 4 -

year period.

Persistence is associated to

serial correlation in growth

rates.

Dillen et

al.

(2014)

$\begin{array}{ll} & \text { period were able to } \\ & \text { maintain the high } \\ & \text { growth rates for } \\ & \text { multiple } \\ & \text { (consecutive) periods. } \\ & \text { Whether the profile } \\ & \text { characteristics of the } \\ & \text { HGF-subsets are } \\ & \text { stable over time. } \\ & \text { Compare profile } \\ & \text { characteristics of the } \\ & \text { so-called 'one-shot } \\ & \text { HGFs' and 'persistent } \\ \text { Daunfeld } & \text { HGFs'. } \\ \text { t and } & \begin{array}{l}\text { Analyse the } \\ \text { Halvarss }\end{array} \\ \text { on } & \begin{array}{l}\text { grobability that high- } \\ \text { (2015) }\end{array} \\ \text { high-growth in } \\ \text { following period, } \\ \text { compared to other } \\ \text { firms. }\end{array}$

Anyadike Fecundity; fertility;
Austria

1985-

2007

Flandres

2000-

2009

Sweden

1997-

2008

OECD definition for high

growth (employment); and

a modified Birch Index to

identify HIF

upon autocorrelation in a

standard Gibrat's model of

size evolution over time

(probability matrix

transition).

\section{OECD definition of HGFs}

(employment and value-

added).

Uses 'overlapping' 3-year

periods.

One shot HGF: employment HGF or value-added HGF in one period.

Persistence is analysed

based upon repeated

events as HGF. Persistent

HGF: firms that could be

identified as a HGF in four

or more periods out of the

seven overlapping periods.

High-growth measured

using quantiles of the firm

growth rate distribution ,

and persistence is analysed

through the probability

matrix transition

Use both number of

employees and total sales.

HGFs are also defined as the

10 and $1 \%$ fastest growing

firms during a 3-year period

growth (consecutive 3-year

period)
Persistence analysed based equation influence performance in the same

way in both periods.

Key strategies help fast growing firms to become or remain a big company. Sustained growth over a long period requires the timely adaption of strategies, both externally and internally

Linear

probabili

ty model

PHGF is even more. About $50 \%$ are not

able to replicate their high-growth

event and are 'one-hit-wonders.'

Age effect is negative but small for

PHGFs.

Industry growth is the most relevant

factor.

HGFs have a higher probability to

became PHGFs. However, the HGF

effect is small.

Overlaps

and

Anova

The majority of the firms that were

identified as an HGF in the period

2000-2009 were 'one-shot HGFs'.

The low number of 'persistent HGFs' is

in line with Gibrat's Law.

Compared to one shot HGF, persistent HGF are larger, older, with larger assets, but differences are higher when employment is used as measure. No difference in terms of solvency (or slightly better for oneshot).

Quantile autocorr

The probability that high-growth firms will repeat high growth is the same elation that some random company would model by have.

Li et al. Fast growing firms are likely to show

(2012). declining growth in the next period. 


$\begin{array}{ll}\begin{array}{l}\text {-Danes } \\ \text { and Hart }\end{array} & \begin{array}{l}\text { survival; and growth } \\ \text { (2015) }\end{array} \\ & \begin{array}{l}\text { Do HGF. } \\ \text { repeated episodes of }\end{array} \\ & \text { high growth? } \\ & \text { What is the } \\ & \text { contribution of HG } \\ & \text { firms for job- } \\ & \text { generation?. } \\ \text { Bianchini } & \text { Identify the factors } \\ \text { et al. } & \text { that distinguish } \\ \text { (2016) } & \text { PHGfs. } \\ & \text { Study firm's } \\ & \text { attributes in } \\ & \text { forecasting the } \\ & \text { probability that a firm } \\ & \text { is HGFs, PHGFs or } \\ & \text { other firms }\end{array}$

Guarasci Study if persistent o,and innovators grow Tamagni more than other

(2016) firms, and if innovation persistence can contribute to explain the little evidence in favor of persistence in growth itself.

\section{Moschell Study if there are} a et al. firm-specific

(2017) attributes that distinguish PHGFs from simple highgrowth

\section{8-}

2013 events over a time period

\section{Italy, \\ HGFs are those companies}

Spain,

French,

UK 2004-

2012

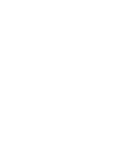

Spain

1990-

2012

China

1998-

2007

$\begin{array}{ll}\begin{array}{ll}\text { Satterth } \\ \text { waite }\end{array} & \begin{array}{l}\text { Study if firm age } \\ \text { and }\end{array} \\ \text { and } & \text { characterize HGFs } \\ \text { Hamilton } & \text { and explain the } \\ \text { (2017) } & \text { persistence of their } \\ & \text { initial high-growth } \\ & \text { phase. } \\ & \text { Study what happens } \\ & \text { to HGFs and the jobs } \\ & \text { their growth created. }\end{array}$

five) years into the top $10 \%$ (employment).

Persistence is repeated HG (frequency distribution of the 3,331 HGFs by number of episodes)

\section{ratios}

and

demogra

phic

accounti

ng

framewo

rk

whose average growth rate

falls into the top $10 \%$ of the

average growth rates

distribution, in terms of

sales or number of

employees.

PHGFs are those firms

whose annual growth rate

falls for at least four (out of

of the yearly cross-sectional

distribution of either sales

or employment growth (or

both).

Firm growth in terms of

sales.

Persistence is the

correlation between growth rates.

HGFs are firms in the top
$20 \%$ of the three-years
average growth rates
distribution in terms of
employment or turnover.
Persistence is the HG status
in two consecutive periods.
Eurostat-OECD (2007)
definition of HGFs as
repeated HG events over
time.
nal probit

OLS
OLS

Linear probabili ty model and regressio $\mathrm{n}$ analysis

Chi-

square test statistic and graphical analyes

The HGFs of cohort98 were not 'one hit wonders'.

Half of all HGFs have a further episode of high growth in the next growth period, but after three periods the repeat proportion is down to $10 \%$. HGFs have only a moderately better chance of surviving than other firms of comparable size.

Multino PHGFs do not systematically differ mial and from others. Services was significant. conditio Firm size and age are not key features and rare- The persistence in $\mathrm{HG}$ seems to be event linked to contingent conditions, both logit internal or external to the firm, regressio whereas not related to structural n characteristics. Persistent innovators do not certainly Quantile grow more, and they may even grow regressio less than other firms. On a long-in-time, the persistence of high-growth is not affected by persistence in innovation.

Some persistence of the HG firms and some firms that are not $\mathrm{HG}$ have around $28 \%$ probability to become $\mathrm{HG}$ firms in future.

None of the structural character-ristics and performance displays statistical association with HPGFs.

Productivity is positive associated with PHFs that are state-controlled Many HGFs died while the majority survived with lower growth rates. Smaller firms are more likely to become HGFs, but the ability to sustain $\mathrm{HG}$ is independent of initial firm size and age The majority of HGFs do remain alive, continuing to contribute disproportionately to employment, but this contribution wanes over time. 
Existing evidence is not only scant but also inconclusive. Not Much effort has done to totally learn the distinguishing features of PHGFs. The lack of empirically studies on HGFs during crisis, combined with the low evidence base surrounding the distinguished features of PHGFs, creates room for miscomprehension as to how persistence emerges and how HGFs contribute to economies. To fill this research gap, a study of the growth patterns and of the HGFs and PHGFs during the recent economic crises were done.

\section{Methodology and Data}

\subsection{Data}

Firm-level data are from IES (Inquérito Empresarial Simplificado), a database maintained by the BPLim of Bank of Portugal. The IES database contains balance sheet data for Portuguese firms from 2006 to 2014, in all sectors. We have a time interval of 9 years that cover the recent enduring crisis period that hunted the Portuguese economy. The working sample is formed by continuing incumbent firms. Firms that entered after 2006 or exited before 2014 have been eliminated, leading to a fixed number of firms over the sample time window. Our analysis counts both manufacturing and services. The final sample counts 190,247 firms. All firms are classified according to 4 digits of NACE classification.

The empirical focus on Portugal is appropriate for three main motivations. First, solving the growth potential of the private sector has constantly been at the center of the discussions on how to enhance economic growth in Portugal. Furthermore it has increased during and after the recent economic crisis (as in many other European Countries). As such, Portuguese policy makers support the goal of promoting HGFs within their policy agendas. This empirical research will help to improve policy design targeting HGFs in Portugal. Second, by having company information for the whole firms that are effective in Portugal for a 8-year period (i.e. from 2006-2014), high growth and persistent high growth patterns could analyzed over a crisis period. Finally, we did not identify persistent high-growth studies on Portugal published in refereed scientific journals.

\subsection{High-growth and Persistent High-growth Operative Definition and Analysis}

Firm growth is computed in the period from 2007 to 2014, distinguishing between HGFs, PHGFs and other firms. In order to identify firms already in activity before the beginning of the crises in 2007, we use data from 2006.

As previously discussed, literature presents many different criterion able to identify HGFs and PHGFs. In this study, we follow the approach suggested by Bianchini et al. (2016), with minor adaptations in line with the purpose of our study and to the available dataset. This approach seeks to identify firms that perform other firms continuously over a reasonably prolonged number of years: we computed the annual growth of firm $i$ in year $t\left(g S_{i t}\right)$, as the difference of firm size $\left(S_{i}\right)$ between year $(\mathrm{t})$ and year $(\mathrm{t}-1)$ :

$$
g S_{i t}=S_{i t}-S_{i, t-1}
$$




$$
S_{i t}=\log \left(S_{i t}\right)-\frac{1}{N} \sum_{i=1}^{k} S_{i t}
$$

Being firm size $\left(S_{i t}\right)$ measured as either number of personnel or sales, adjusted by the average size of the $\mathrm{N}$ firms of the same sector. We normalize firms' annual growth rates by the annual sectoral average and then we computed the annual growth for each year of the period from 2007 to 2014.

We set as HGFs those firms whose average growth rate during the analyzed crises interval falls into the top $20 \%$ of the average growth rates distribution, in terms of at least number of employees or sales. Once identified HGFs, we prevent the confusing influences enacted by the usual uncertainty of growth patterns over time.

PHGFs are defined as those firms whose annual growth rate falls for at least five years (out of seven) into the top $20 \%$ of the yearly cross-sectional distribution of at least number of workers or sales growth. The criteria used for defining PHGFs accounts for Bianchini et al. (2016) note regarding the need to balance between the goal of capturing companies that outperform the others repeatedly over time and the need to detect a set that enables us to perform important statistical analysis(Note 2).

Table 2 reports the number of HGFs and PHGFs over the period 2007-2014. HGFs account for nearly $22 \%$ of the full sample. Compared with descriptive statistics from previous literature, our values are sensible higher, which is not surprising considering that we have defined less restrictive limits for defining HGFs and PHGFs (see e.g. Bianchini et al., 2016).

Table 2. High Growth and Persistent High Growth Firms (2007-2014)

\begin{tabular}{lcc}
\hline Type of firm & Number of firms & Share (\%) \\
\hline High growth (HGFs) & 42,358 & 22.26 \\
High growth (exc. PHGFs) & 38,000 & 19.97 \\
Persistent high growth (PHGFs) & 4,597 & 2.42 \\
Other (exc. PHGFs and HGFs) & 147,650 & 77.61 \\
Total & 190,247 & 100,00 \\
\hline
\end{tabular}

Based on previous issues, we would presume to face a restricted amount of HGFs that are able to realize persistent high growth rates. Out of the $42,358 \mathrm{HGFs}$, about $10 \%(4,358)$ of them are also persistent high growth. When applying our criteria, 4,597 PHGFs were identified. Hence, about $5 \%$ of PHGFs are those companies not classified as HGFs.

Even if a large majority of firms did not classify as persistent high growth, this set of firms have been very important from a macroeconomic point of view. As shown in the Figure 1, high growth, but mainly persistent high growth firms have been accountable for the majority of the turnover (Panel A) and employment (Panel B) growth over the time period analyzed. PHGFs 
turnover increased more than $87.10 \%$, while that for HGFs increased $59.12 \%$. The remaining group of 'other firms' registered a decline in turnover of $-25.48 \%$. In what regards employment, PHGFs registered an increase of $111.62 \%$ and HGFs of $53.05 \%$. Total employment of the 'other firms' group, declined by $-24.71 \%$.

As a result, the share of PHGFs in terms of total employment (Panel C) and total turnover (Panel D) has increased over the analyzed time period.

Turning to an analysis by sector of activity, high growth and persistent high growth are phenomenon present in all sectors even if they account for a larger share in services than in manufacturing. These sectors have relatively higher intensity of PHGFs.

PHGFs are concentrated in wholesale trade (10.81\%), specialized construction activities $(8.11 \%)$, retail trade $(8.07 \%)$, construction of buildings $(7.42 \%)$, human health activities $(4.76 \%)$, manufacture of fabricated metal products, except machinery and equipment $(3 \%)$, and manufacture of food products (2,55\%). Hence, PHGFs are under-represented in hightechnology sectors and occur in any industry.

The picture for HGFs is relatively similar, with the largest shares being concentrated in wholesale trade $(11.50 \%)$, retail trade $(11.54 \%)$, human health activities $(8.17 \%)$, construction of buildings $(6.81 \%)$, food and beverages activities $(6.20 \%)$ among services, and manufacture of fabricated metal products, except machinery and equipment $(2.29 \%)$, manufacture of food products $(2.01 \%)$, specialized construction activities $(8.11 \%)$ among manufacturing.

In order to control for size and number of firms in the sector, we computed two ratios:

$$
\text { Ratio } H G i=S \_H G i / S \_F i
$$

Being $S \_H G i$ the share of the HGFs of sector $i$ on the total number of HGFs, and $S \_F i$ the share of firms of sector $i$ on total number of firms. If the ratio is below one, it means that the share of the sector on total HGFs is below than expected, considering its contribution to the total number of firms. Otherwise, if the ratio is higher than one, it means that the share of the sector on total HGFs is higher than expected, considering its contribution to the total number of firms.

$$
\text { Ratio PHGi }=S \_P H G i / S \_F i
$$

Being $S \_P H G i$ the share of the PHGFs of sector $i$ on the total number of PHGFs, and $S \_F i$ the share of firms of sector $i$ on total number of firms. If the ratio is below one, it means that the share of the sector on total PHGFs is below than expected, considering its contribution to the total number of firms. Otherwise, if the ratio is higher than one, it means that the share of the sector on total PHGFs is higher than expected, considering its contribution to the total number of firms.

The results for the industry ratios, both for manufacturing and services, are represented in Figure 1(Note 3). 
(A) Employment Growth rate

(B) Turnover Growth rate

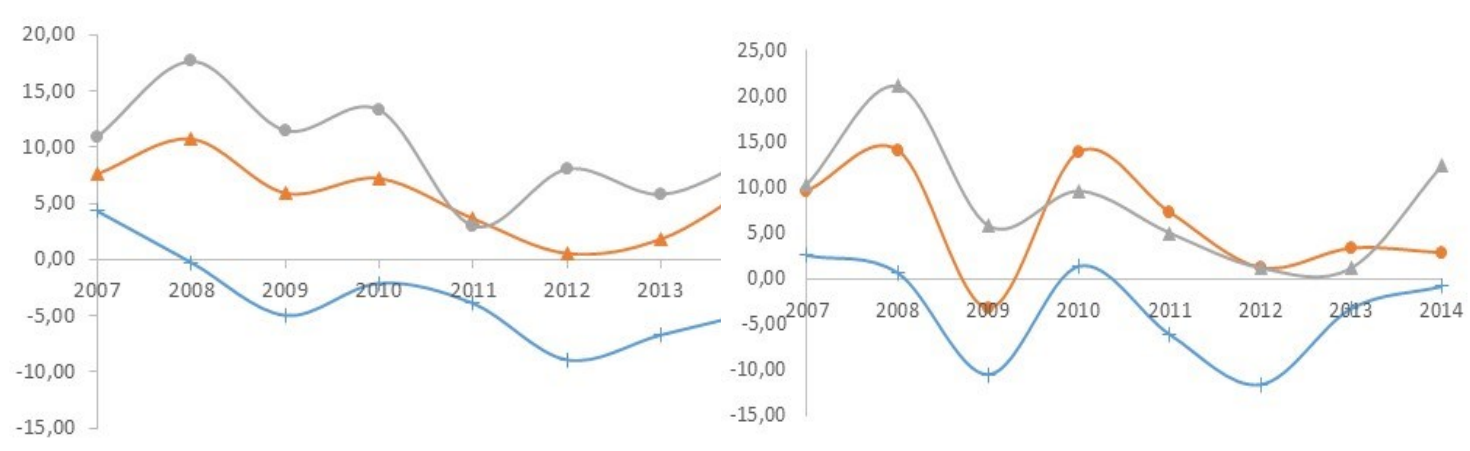

(C) Share on total employment

(D) Share on turnover
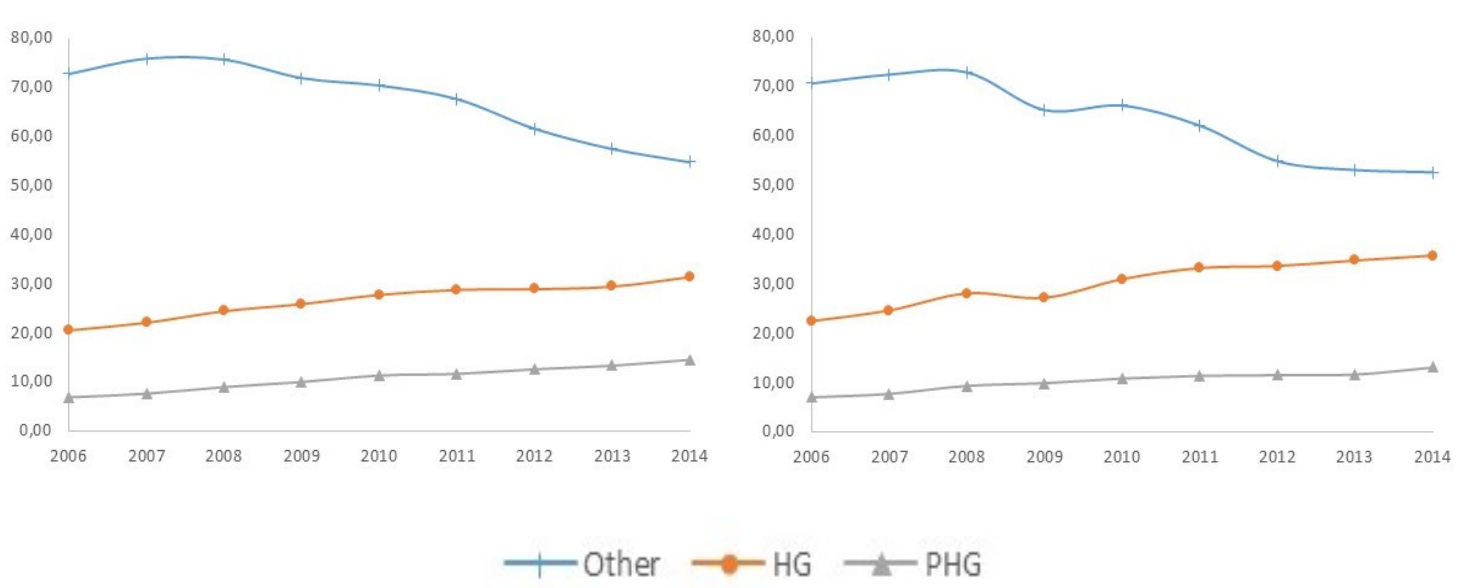

Figure 1. Employment and Turnover Evolution over Time by type of Firms

\subsection{Model and Explanatory Variables}

\subsubsection{Explanatory Variables}

Drawing upon previous studies, we considered eight level firm factors that are expected to contribute to differentiate high growth: profitability, productivity, financial conditions, internationalization, innovativeness, age, size and sector. To the best of our knowledge this is the first study testing for the effect of internationalization upon persistence of high growth. We explore if firms with a relative advantage in these aspects are more likely not only to register high-growth but also persistent high growth. In addition we explore whether HG firms are more likely to be PHGFs.

Return on assets, defined as EBITDA over total assets (Profitability), is the measure of profitability, while as measure for productivity we considered an index defined as value-added over total labor costs (Productivity). Two indicators capture two different dimensions of 
financial status: liquidity and indebtedness. It was used a standard measure of liquidity, computed as the ratio between assets and liabilities (Liquidity) and a measure of indebtedness measured as an index of total assets over equity (Indebtedness). The value of intangible assets is used as a proxy for innovative capacity (Innovation), while for internationalization we considered the share of exports on sales (Internationalization). Finally, we considered age of the firms determined by the difference between 2006 and the year of star-up (Age). The logarithm of the number of employees was used as the proxy for size (Size). In order to account for sectoral specificities, we considered whether the firm belongs to services (Services) and also the degree of market concentration, using a typical measure of industry concentration, the Herfindhal Index (Concentration). Higher levels of concentration are expected to represent lower competition, and eventually may contribute to higher growth of firms.

Table 3 provides descriptive statistics by growth status, considering the initial 2006 characteristics and the means for the overall period.

The whole picture, without focusing on specific differences across growth status, indicates an improvement on liquidity but a high increase in indebtedness, while profitability registered a slight decline compared to the baseline year of 2006. Firms registered increases in terms of size, innovation and degree of internationalization, while productivity has not changed or slightly declined.

Table 3. Descriptive Statistics accordingly to Growth Status

\begin{tabular}{ccccccc}
\hline & \multicolumn{3}{c}{ Mean (2006) } & \multicolumn{3}{c}{ Mean (2006-2014) } \\
\cline { 2 - 7 } & Other & HGFs & PHGFs & Other & HGFs & PHGFs \\
\hline Profitability & 0.11 & 0.13 & 0.12 & 0.06 & 0.10 & 0.11 \\
Productivity & 1.89 & 2.20 & 1.92 & 1.70 & 2.09 & 1.97 \\
Liquidity & 3.11 & 3.04 & 2.22 & 4.53 & 3.86 & 2.41 \\
Indebtedness & 1.82 & 1.87 & 1.85 & 3.50 & 3.60 & 3.86 \\
Internationalisation & 4.37 & 5.44 & 9.01 & 4.35 & 6.09 & 10.52 \\
Innovation & 83758 & 113,536 & 867,830 & 76,296 & 177,441 & $1,278,901$ \\
Age & 12.89 & 10.10 & 8.59 & 17.53 & 14.52 & 12.73 \\
Size & 13.37 & 12.83 & 31.87 & 12.51 & 15.27 & 44.77 \\
\hline
\end{tabular}

Concentrating on variations across growth status, patterns appear. Compared to other firms' category, HGFs show slightly less liquidity and more indebtedness. Results for profitability are very similar, but higher for HGFs which are also more productive, show higher degree of internationalization and higher innovativeness than the set of 'other firms'. In line with existing literature, HGFs tend to be smaller and younger than the group of other firms.

Overall, PHGFs display slight lower liquidity, lower indebtedness, lower profitability and lower productivity than HGFs. They tend to be younger, but larger. PHGFs display larger degree of internationalization and higher innovativeness than HGFs. 


\subsubsection{Model}

In order to test the determinants of high growth and persistent high growth, we applied an econometric procedure involving two phases. First we followed a standard multivariate regression analysis, examining the role of firm traits in predicting the probability that a firm belongs to one of the three groups of HGFs, PHGFs and other firms. The probability to belong to each group is modeled as a function of a set of explanatory variables (i.e. profitability, productivity, liquidity, indebtedness, internationalization, innovation, age and size). Regressors also account for sectoral specificities. Specifically, we include a dummy for service firms and the degree of market concentration. We considered a lag between initial firm characteristics (measured in 2006, the year previous to the growth sample period) and growth status during the crises period (2007-2014). This procedure reduces potential simultaneity bias. We estimate a multinomial probit model with independent idiosyncratic components across the different categories since the dependent variable, growth status, is a categorical unordered variable, with three categories. The categories are coded 1 to 3, being 1-other firms, 2-HGFs, and 3- PHGFs, where the numbers are only codes and their magnitude cannot be interpreted. Defining HGFs as the baseline, a positive (negative) estimated coefficient indicates that the corresponding regressor increases (decreases) the odds of belonging to the group of other firms or to the group of PHGFs, with respect to be in the HGFs group.

In the second phase we explore which characteristics of a HGFs affects the probability of being a PHGFs. The dependent variable is whether the firm is a persistent growth one (dummy variable equal to 1 ) or not (dummy variable equal to 0 ). The dependent variable is binary and we use a logistic regression model. As explanatory variables we considered the high growth status ( 1 if the firm was HGF, 0 otherwise), and the same set of variables described for the previous model. A positive (negative) coefficient and positive (negative) $z$ signal that the variable increases (decreases) the odds of being a PHGF.

\section{Regression Results}

Table 4 shows our results for the analysis, the coefficients together with robust standard errors. Model 1 reports the estimates obtained for the odds of being other firms against being an HGFs, while results for Model 2 show how firm and industry characteristics associate with the odds of being a PHGF rather than an HGF.

The results obtained for the other firms signal that HGFs are more profitable (the coefficient of Profitability is negative and significant at $\mathrm{p}<0.001$, Model 1 ) and are more productive (the coefficient of Productivity is negative and significant at $p<0.001$, Model 1 ), in line with the theoretical predictions. The results confirm that profitability and productivity do not impact on the firm's status. The results for the financial variables reveal that HGFs tend to have lower liquidity (the coefficient of Liquidity is positive and significant at $\mathrm{p}<0.001$, Model 1 ), but also lower indebtedness (the coefficient of Indebtedness is positive and significant at $p<0.001$, Model 1). Internationalization presents a negative and significant coefficient (at $\mathrm{p}<0.001$, Model 1), revealing that HGFs tend to be more involved in international activities. The 
coefficients of Age and Size are positive and significant at $\mathrm{p}<0.001$ in Model 1, with HGFs being younger and smaller. The Service dummy has a positive and significant coefficient (at $\mathrm{p}<0.001$, Model 1), reflecting that higher growth was more likely to occur among manufacturing rather than service firms. Being the later more directed to the domestic market, these sectors might have seen their growth more penalized during the recent crises. Regarding the industry concentration ratio, the negative result signals that HGFs tend to be in sectors with higher concentration (the coefficient of Concentration is negative and significant at $p<0.001$, Model 1). In sectors with lower industry concentration (i.e. higher competition) growth tends to be lower.

Table 4. Multinomial Probit Model

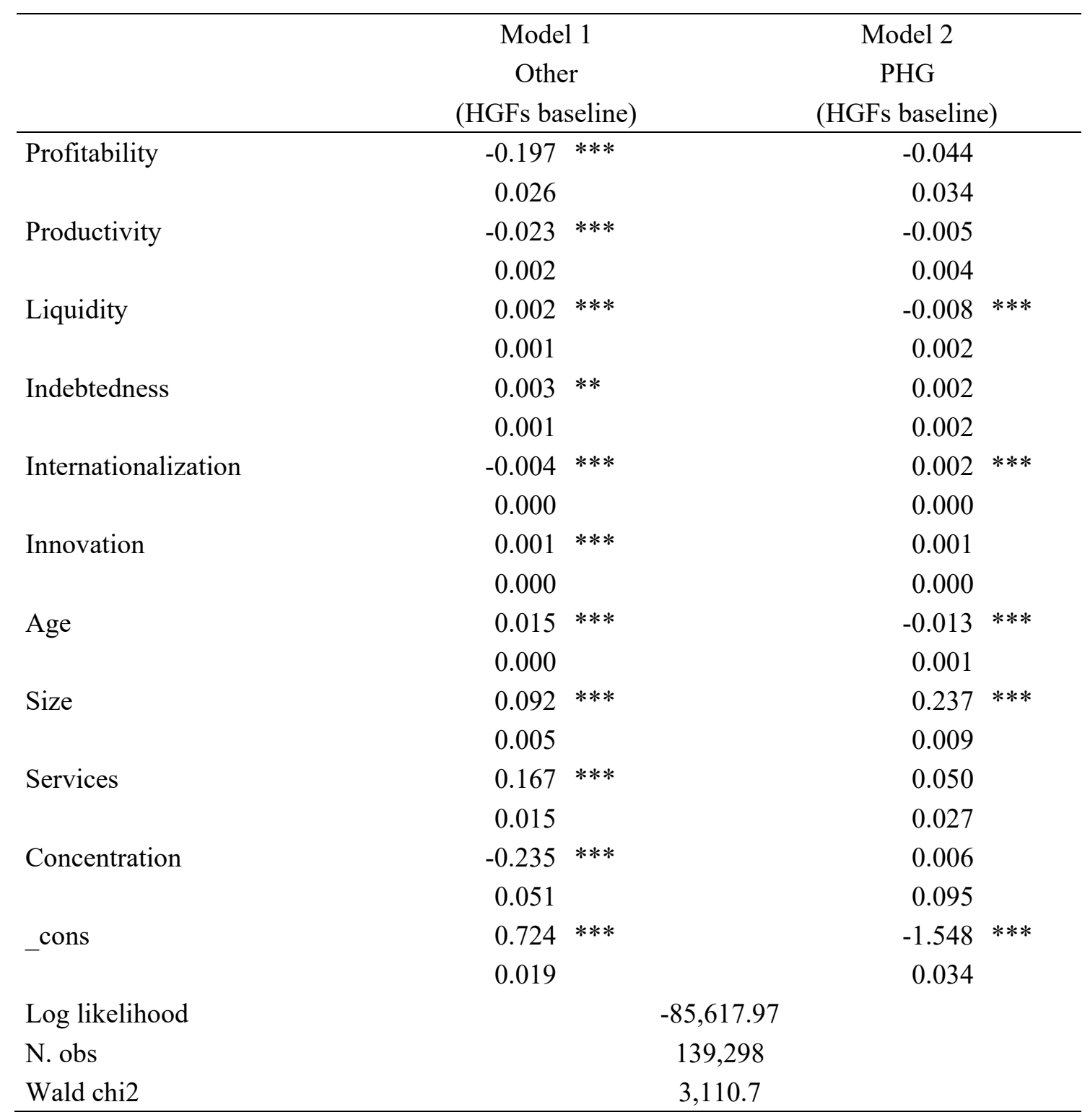

Note: $* * *: \mathrm{p}<0.001 ; * *: \mathrm{p}<0.005$ 


\section{Macrothink Institute ${ }^{\mathrm{TM}}$}

In the right panel where we account the estimates for PHGFs, our results show that higher liquidity reduce the odds of being HGF and PHGF (the coefficient of Liquidity is negative and significant at $\mathrm{p}<0.001$, Model 2). Internationalization has a significant and positive coefficient (significant at $\mathrm{p}<0.001$, Model 2). The results match previous evidence that PHGFs are more likely to be younger (the coefficient of Age is negative and significant at $\mathrm{p}<0.001$, Model 2) and larger (the coefficient of Size is positive and significant at $\mathrm{p}<0.001$, Model 2). No significant coefficients were found regarding Profitability, Productivity, Indebtedness, Innovation and Concentration.

Overall, being younger and highly internationalized increases both the odds of being HGF and PHGF. Instead, size is a structural characteristic that allows to distinguish the three categories, but the effect of size works in an opposite way for HGF and PHGF. While smaller firms have registered higher growth compared to other ones, PHGF tend to be larger.

Next we explore the probability of being a PHGF (Table 5, Model 3). The dependent variable is whether the firm is a PHGF (dummy variable equal to 1 ) or not (dummy variable equal to 0 ).

Table 5. Logist Regression Model

\begin{tabular}{lccc}
\hline & Coef & $\mathrm{Z}$ & Odds ratio \\
\hline HGFs & 4.311 & 52.93 & $74.540 * * *$ \\
Profitability & 0.010 & 0.12 & 0.010 \\
Productivity & -0.004 & -0.55 & 0.996 \\
Liquidity & -0.015 & -3.42 & $0.985 * * *$ \\
Indebtedness & 0.003 & 0.83 & 1.003 \\
Internationalization & 0.005 & 5.77 & $1.005 * * *$ \\
Innnovation & 0.000 & 0.94 & 1.000 \\
Age & -0.030 & -10.89 & $0.971 * * *$ \\
Size & 0.366 & 22.65 & $1.442 * * *$ \\
Services & 0.026 & 0.52 & 1.026 \\
Concentration & 0.086 & 0.52 & 1.090 \\
Cons & -6.748 & -65.58 & $0.001 * * *$ \\
Prob $>$ chi2 & & 0.000 & \\
LR CHI2(11) & & $9,722.08$ & \\
N. obs & & 139,298 & \\
Log Likelihood & & $-11,681.59$ & \\
Pseudo R2 & & 0.29 & \\
\hline
\end{tabular}

Note: $* * *: p<0.001 ; * *: p<0.005$

Of course, the results reveal that high-growth firms are more likely to be a PHGF compared to non- HGF (the coefficient of HGFs is positive and significant at $p<0.001$, Model 3 ). Results for the remaining variables confirm the results obtained through the multinomial probit model. In particular, Internationalization and size increase the probability of being PHGF (the 
coefficient of Internationalization and Size are positive and significant at $\mathrm{p}<0.001$, Model 3), while Liquidity and Age are negative and significant (at $\mathrm{p}<0.001$, Model 3). The variables Profitability, Productivity, Indebtedness, Innovation, Services and Concentration are not significant (Model 3).

\section{Conclusion}

The Covid-19 pandemic has generated a massive uncertainty shock, and the most comparable is the one associated with the financial crisis of 2008 (Baker, et al. 2020). Major economic uncertainties are, among others: the near-term economic impact of the pandemic and policy responses, the impact on business survival, new business formation, R\&D investment and development, human capital investment, and productivity (Baker, et al. 2020; Alfaro, et al. 2020). Furthermore, Governments have to deal with a loss of revenue, an increase in the demand for public expenditure, and tightened global financial conditions (Hevia \& Neumeyer 2020; Özpençe, 2017). As such, the definition of public financial incentive in more efficient ways of identifying winning firms is imperative. Whit our analysis we try to give some suggestion in terms of public policy.

Notwithstanding recent literature reveal a weak signal to support specific measures supporting picking winners versus broader provision (Lerner, 2010), nowadays there has been an intensification in attention upon HGFs, with demands for more sharp attitudes to public policy incentive (Anyadike-Danes et al. 2015; Brown and Mawson, 2015; OECD, 2010).

The study shows that very few HGFs are indeed persistent high growth, also in crisis years.

All these aspects have clear consequences for policy makers, since high-growth performances could have more relevant economic impact if they were long lasting and persistent, especially in period such as pandemic. Hence, from a policy perspective, we propose that the programs should mostly be targeted to firms that have the possibility to develop into a HGF instead of the firms that have previously attained the status of a HGF. In fact, many firms will vanish from policy attention before targeted support can reach them given the transience of their highgrowth phase (Brown and Mawson, 2015).

A main implication of our study is that future studies on HGFs should preferably take the distinction between PHGFs and simply HGFs into account as they embody two unique types of high growth firms. In a managerial perspective, HGFs are frequently thought to be a kind of best practice. However, managers have to recognize that a significant amount of the HGFs are one-shot HGFs whose great growth rates may be linked to an unintentional or unforeseen growth increase in a specific time. Once More, the PHGFs' may do better as a best practice in terms in managerial perspectives.

Covid-19 crisis is conducting to important reductions in business investments both on innovation and internationalization, training and general management advancements, which we expect to lower productivity into 2021 and beyond (Baker, et al. 2020). In order to mitigate such conditions leading to unemployment, our analysis suggest to finance in particular firms 
that are internationalized.

Future research should investigate the reasons that avoid the high growth from preserving their high growth rates for a longer time period. We suggest to investigate the location distribution of the two high growth groups. Further, the determinants of the high growth rates that are released by the PHGFs and the one-shot HGFs, can be studied in next studies as this work only measured specific traits of this two groups of HGFs. As concern the drop-out firms, further study can be done in the next years. When performing case studies in HGFs, concentrating on the PHGFs could give new comprehensions as these groups of firms have demonstrated to be able of maintaining high growth for a prolonged time. Given their robust path record of high growth, these firms could be more appropriate for case analyses that have the objective to examine the factors of high business growth.

\section{References}

Acs, Z., Parsons, W., \& Tracy, S. (2008). High-impact firms: Gazelles revised. Small Business Research Summary, 328, 1-43.

Alfaro, L. (2020). Aggregate and firm-level stock returns during pandemics in real time. w26950. National Bureau of Economic Research. https://doi.org/10.2139/ssrn.3562034

Anyadike-Danes, M., Hart, M., \& Du, J. (2015). Firm dynamics and job creation in the United Kingdom, 1998-201. International Small Business Journal, 33(1), 12-27. https://doi.org/10.1177/0266242614552334

Anyadike-Danes, M., \& Hart, M. (2015). Fecundity, fertility, survival and growth: High growth firms in the UK and their contribution to job creation. A demographic perspective. Working Paper. 20 September.

Audretsch, D. B., Coad, A., \& Segarra, A. (2014). Firm growth and innovation. Small Business Economics, 43(4), 743-749. https://doi.org/10.1007/s11187-014-9560-X

Baker, S. R., Bloom, N., Davis, S. J., \& Terry, S. J. (2020). Covid-induced economic uncertainty. National Bureau of Economic Research. w26983. https://doi.org/10.3386/w26983

Barro, R. J. J., Ursúa, F., \& Weng, J. (2020). The coronavirus and the great influenza pandemic: Lessons from the Spanish flu for the coronavirus's potential effects on mortality and economic activity. National Bureau of Economic Research. w26866. https://doi.org/10.3386/w26866

Bianchini, S., Bottazzi, G., \& Tamagni, F. (2016). What does (not) characterize persistent corporate high-growth? Small Business Economics, 48(3), 633-656. https://doi.org/10.1007/s11187-016-9790-1

Birch, D. L. (1979). The Job Generation Process. Research report. MIT Program on Neighborhood and Regional Change. Cambridge. MA. 
Birley, S. (1987). New ventures and employment growth. Journal of Business Venturing, 2(2), 155-165. https://doi.org/10.1016/0883-9026(87)90005-X

Brown, R., \& Mawson, S. (2015). Targeted support for high growth firms: Theoretical constraints. Unintended consequences and future policy challenges. Environment and Planning C: Government and Policy, 34(5), 816-836. https://doi.org/10.1177/0263774X15614680

Brown, R., \& Mawson, S. (2013). Trigger points and high-growth firms: A conceptualisation and review of public policy implications. Journal of Small Business and Enterprise Development, 20(2), 279-295. https://doi.org/10.1108/14626001311326734

Brown. R., \& Mawson, S. (2016). The geography of job creation in high growth firms: the implications of 'growing abroad. Environment and Planning C: Government and Policy, 34(2), 207-227. https://doi.org/10.1177/0263774X15614152

Burgel, O., Fier, A., Licht, G., \& Murray, G. (2003). Internationalisation of high-tech start-ups and fast-growth: evidence for UK and Germany. ZEW Discussion Paper, 00-35. https://doi.org/10.2139/ssrn.373940

Carré, E., \& L'œillet, G. (2018). The Literature on the Finance-Growth Nexus in the Aftermath of the Financial Crisis: A Review. Comparative Economic Studies, 60(1), 161-180. https://doi.org/10.1057/s41294-018-0056-6

Chanut-Guieu, C., \& Guieu, G. C. (2014). High growth trajectories in small and medium sized enterprises: A comparative study. Journal of Small Business and Enterprise Development. https://doi.org/10.1108/JSBED-09-2014-0151

Coad, A. (2007). A closer look at serial growth rate correlation. Review of Industrial Organization, 31(1), 69-82. https://doi.org/10.1007/s11151-007-9135-y

Coad, A. (2009). The growth of firms: A survey of theories and empirical evidence. Cheltenham: Edward Elgar Publishing. https://doi.org/10.4337/9781848449107

Coad, A., \& Hölzl, W. (2009). On the autocorrelation of growth rates. Journal of Industry Competition and Trade, 9(2), 139-166. https://doi.org/10.1007/s10842-009-0048-3

Coad. A., \& Nightingale, P. (2014). Muppets and gazelles: political and methodological biases in entrepreneurship research. Industrial and Corporate Change, 23(1), 113-143. https://doi.org/10.1093/icc/dtt057

Coad, A., Daunfeldt, S., Hölzl, W., Johansson, D., \& Nightingale, P. (2014). High-growth firms: Introduction to the special edition. Industrial and Corporate Change, 23(1), 91-112. https://doi.org/10.1093/icc/dtt052

Daunfeldt, S., \& Halvarsson, D. (2015). Are high-growth firms one-hit wonders? Evidence from Sweden. Small Business Economics, 44(2), 361-383. https://doi.org/10.1007/s11187-014-9599-8

Dillen, Y., Laveren, E., Martens, R., De Vocht, S., \& Van Imschoot, E. (2014). Growth 
persistence and profile robustness of high-growth firms. International Journal of Entrepreneurial Venturing, 6(4), 299-330. https://doi.org/10.1504/IJEV.2014.066836

European Commission (2010). Europe 2020: A Strategy for Smart. Sustainable and Inclusive Growth. Communication from the Commission. European Commission Publications Office: Brussels. Belgium.

Geroski, P. (2000). The growth of firms in theory and practice. In N. Foss \& V. Mahnke (Eds) Governance. Competence and Entrepreneurship (Oxford: Oxford University Press).

Giotopoulos, I., Kontolaimou, A., \& Tsakanikas, A. (2017). Antecedents of growth-oriented entrepreneurship before and during the Greek economic crisis. Journal of Small Business and Enterprise Development. https://doi.org/10.1108/JSBED-01-2017-0003

Guarascio, D., \& Tamagni, F. (2016). Persistence of innovation and patterns of firm growth. LEM Working Papers, 31. Sant'Anna School of Advanced Studies. Pisa. Italy.

Haiss, P., Hannes, J., \& Mahlberg, B. (2016). The impact of financial crises on the financegrowth relationship: A European perspective. Economic Notes: Review of Banking, Finance and Monetary Economics, 45(3). 423-444. https://doi.org/10.1111/ecno.12067

Hansen, B., \& Hamilton, R. (2011). Factors distinguishing small firm growers from nongrowers. International Small Business Journal, 29(3). 278-294. https://doi.org/10.1177/0266242610381846

Henrekson, M., \& Johansson, D. (2010). Gazzelles s job creators: a survey and interpretation of the evidence. Small Business Economics, 35(2), 227-244. https://doi.org/10.1007/s11187-009-9172-z

Hevia, C., \& Neumeyer, A. (2020). A conceptual framework for analyzing the economic impact of covid-19 and its policy implications. UNDP LAC COVID-19 Policy Documents Series, 1(29).

Hölzl, W. (2014). Persistence, Survival and growth: A closer look at 20 years of fast-growing firms in Austria. Industrial and Corporate Change, 23(1), 199-231. https://doi.org/10.1093/icc/dtt054

Huggins, R., Morgan, B., \& Williams, N. (2015). Regional entrepreneurship and the evolution of public policy and governance. Journal of Small Business and Enterprise Development, 22(3). https://doi.org/10.1108/JSBED-12-2012-0135

Lerner, J. (2010). The future of public efforts to boost entrepreneurship and venture capital. Small Business Economics, 35(3), 255-264. https://doi.org/10.1007/s11187-010-9298-z

Li, J., Zhang, Y., Yang, X., \& Ma, F. (2008). A quantitative analysis of the characteristics of rapid-growth firms and their entrepreneurs in China. Journal of Small Business and Enterprise Development, 15(4). https://doi.org/10.1108/14626000810917799

Loayza, N., Amine, O., \& Ranciere, R. (2017). Financial development, growth and crisis: is there a trade-off? The World Bank. https://doi.org/10.1596/1813-9450-8237 
Lu, J. W., \& Beamish, P. W. (2001). The internationalization and performance of SMEs. Strategic Management Journal, 22(6-7). 565-586. https://doi.org/10.1002/smj.184

Mohr, V., \& Garnsey, E. (2011). How do high-growth firms grow? Evidence from Cambridge, UK, Economics. Management and Financial Markets, 6(4), 29-59. https://doi.org/10.2139/ssrn.1923033

Molinari, M., Giannangeli, S., \& Fagiolo, G. (2016). Financial Structure and Corporate Growth: Evidence from Italian Panel Data. Economic Notes, 45(3), 303-325. https://doi.org/10.1111/ecno.12059

Moschella, D., Tamagni, F., \& Yu, X. (2017). Persistent high-growth firms in China's manufacturing. Institute of Economics. Scuola Superiore Sant'Anna. Pisa. Italy. ISSN(ONLINE) 2284-0400.

Nylund, P. A., Hernandez, X. F., Serrat, N. A., Portet, X. G., Freixanet, M. F., \& Aliberch, A. S. (2016). High-growth Firms in low-growth regions: Internationalization as a predictor of growth. International Business Management, 10(4), 320-323.

OECD (1996). Innovation firm size and market structure: Schumpeterian hypothesis and some new themes. Economic Department Working Papers, 161.

OECD (2010). High-growth Enterprises: What Governments Can Do to Make a Difference. OECD: Paris. France. https://doi.org/10.1787/9789264048782-en

O'Gorman, C. (2001). The sustainability and growth in small and medium sized enterprises. International Journal of Entrepreneurial Behavior and Research, 7(2), 60-75. https://doi.org/10.1108/13552550110396095

Özpençe, A. İ. (2017). Economic Stability and Growth: The Case of Turkey. Research in Applied Economics, 9(4), 41-63. https://doi.org/10.5296/rae.v9i4.12041

Ostgaard, T. A., \& Birley, S. (1996). New venture growth and personal networks. Journal of Business Research, 36(1), 37-50. https://doi.org/10.1016/0148-2963(95)00161-1

Panizza, U. (2018). Nonlinearities in the Relationship between Finance and Growth. Comparative Economic Studies, 60(1), 44-53. https://doi.org/10.1057/s41294-017-00433

Parker, S. C., Storey, D. J., \& van Witteloostuijn, A. (2010). What happens to gazelles? The importance of dynamic management strategy. Small Business Economics, 35(2), 203-226. https://doi.org/10.1007/s11187-009-9250-2

Reichstein, T., \& Dahl, M. S. (2004). Are Firm Growth Rates Random? Analysing Patterns and Dependencies. International Review of Applied Economics, 18(2), 225-246. https://doi.org/10.1080/0269217042000186705

Satterthwaite, S., \& Hamilton, R. T. (2017). High-growth firms in New Zealand: Superstars or shooting stars? International Small Business Journal, 35(3), 244-261. https://doi.org/10.1177/0266242616659913 
Siddiqui, K. (2009). Financial crisis and its impact on the economies of China and India. Research in Applied Economics, 1(1). https://doi.org/10.5296/rae.v1i1.183

Zahra, S. A., Ireland, R., \& Hitt, M. A. (2000). International expansion by new venture firms: international diversity, mode of market entry, technological learning, and performance. Academy of Management Journal, 43(5), 925-950. https://doi.org/10.5465/1556420

\section{Notes}

Note 1. Economic Notes, Volume 45, Issue 3. November 2016 Pages 299-472.

Note 2. The findings do not change if we design a less restrictive criterion. Otherwise, when we apply a more restrictive criteria by imposing that PHGFs should pass the threshold in 6 out of 7 years, the number of PHGFs drops radically, hindering a credible statistical analysis.

Note 3. The results for the industry ratios are available upon request

\section{Copyright Disclaimer}

Copyright for this article is retained by the author(s), with first publication rights granted to the journal.

This is an open-access article distributed under the terms and conditions of the Creative Commons Attribution license (http://creativecommons.org/licenses/by/3.0/). 